\title{
The Embryonic Development of the Submandibular and Sublingual Salivary Glands in the White hat
}

\author{
Rozwój zarodkowy ślinianki podszczęhowej i podjęzykowej \\ szczura bialego
}

[With 6 Figs.]

\author{
I. Introduction \\ II. Material and methods \\ III. Result \\ IV. Discussion of results \\ V. Summary . \\ References \\ Streszczenie
}

\section{INTRODUCTION}

There are no exact data to be found in literature on the formation and development of the large salivary glands in animals. A e be r hard t (1931) in investigating the salivary glands in embryos of the cat and dog, stated that these glands are formed comparatively early and that they possess formed secreting elements as early as the embryo stage. Chievitz (1885) also observed formed secreting elements and the presence of mucous substances, initially only in the apical part of the cells, in the salivary glands of the embryos of different species of animals. On the other hand, J a c o by \& Lees o n (1959), who examined the salivary glands of young rats from the time of birth up to 6 months of age, are of the opinion that in animals formation of the secreting part of the salivary glands does not begin until after the birth of the individual and lasts up to the end of the first 6 weeks of life. In my previous work ( $\mathrm{Szymańska,1962)} \mathrm{I} \mathrm{observed} \mathrm{a} \mathrm{well-formed}$ submandibular and sublingual salivary gland producing secretion in rat embryos originating from the later periods of pregnancy. In man, in the opinion of the embryologists (Hertwig, 1910; Clar a, 1940; P a t te n, 1946; B r and t, 1949; Godlewski, 1950), large salivary glands are formed during the 6 th -8 th week of embryonic life. The mechanism of development of salivary glands in man consists in the formation of compact groups of epithelial cells of ectodermal origin and their growth on a mesenchymatic base ( $\mathrm{P}$ a t te $\mathrm{n}, 1946)$. The formation of thr 
lumen and further differentiation of these compact bands takes place later, in the final period of foetal life.

\section{MATERIAL AND METHODS}

The salivary glands of 42 white rat embryos were used for the purposes of the present study, this number including 4 embryos $22 \mathrm{~mm}$. long, 6 embryos $24 \mathrm{~mm}$. long, 17 embryos $26 \mathrm{~mm}$. long, and 15 embryos $29 \mathrm{~mm}$. long. After incising the skin on the neck of the embryo, the rudiments of both the salivary glands examined were prepared whole, together with the connective tissues surrounding them, and dissected in turn. B o u in, Z $\mathrm{Z}$ nker and $\mathrm{L}$ is on-Voke a r fluids were used as fixing mediums. The preparations made using the paraffin technique were cut into sections 6 microns thick, and stained with haematoxylin-eosine, ferrous haematoxylin, mucicarmine, Haidenhain's "Azan", PAS-ferrum (G r a u m a n n \& Cla uss, 1958) and by the following methods - Himes and Moriber ( $\mathrm{H}$ i m es \& M or i ber, 1956), Feulgen and Brachet (P e a r s e, 1960).

\section{RESULTS}

The youngest embryos in which it proved possible to observe the rudiments of salivary glands were embryos 21 and $22 \mathrm{~mm}$. long. The first. perceptible picture here is formed by the fairly large, compact accumulations of cells (Fig. 1). These cells have distinct, large, spherical nuclei. Both the cytoplasm and the nuclei stain very lightly by the histochemical and histological methods used, and it is only when the Himes-Moriber method is used for staining that the plasm of the cells is distinctly yellow. There is a minimum nuclein acids content. Only the nuclear membrane and the single grains of chromatyne are visible in the nucleus. There are a large number of caryokinetic fissions.

In white rat embryos $24 \mathrm{~mm}$. long (Fig. 2) a sort of fission takes place, fragmentation of the compact formations constituting the rudiments of the salivary glands. Folds appear on their surface and in this way small, initially compact, groups of cells are gradually isolated, and a lumen next appears in them. It is possible here to distinguish formations with a fairly large lumen - rudiments of outlet ducts, and small round-shaped elements with a scarcely perceptible lumen - rudiments of the secreting sections - vesicles. During this period the results of staining with mucicarmine, PAS-ferrum and "Azan" are negative. When stained by the Himes-Moriber method the cytoplasm of all the elements is yellow. DNA and RNA contents are slightly greater here than previously, but still small. A large amount of cells in process of fission are visible. On account of the vesicular structure and the topography it must be assumed that these are the rudiments of the submandibular salivary gland.

In embryos $26 \mathrm{~mm}$. long, in addition to the rudiments of the subman- 
dibular salivary gland, for the first time it proved possible to observe rudiments of the mucous sublingual salivary gland. The submandibular gland during this period consists of distinct vesicles and of ducts (Figs. $3,4,5)$. The vesicles are somewhat irregular in shape, and are formed by cells containing large, spherical nuclei, which give a fairly strong Feulgen reaction. Protoplasm gives a strong Brachet reaction, stains yellow, and in the apical part stains red by the Himes-Moriber method. Staining with mucicarmine reveals the presence of mucus in the apical part of the cells. Thus, as early as this stage of development of the submandibular salivary gland of the rat, the muco-serous character of its secreting cells is perceptible, but purely mucous elements are absent. The ducts are not as yet differentiated into the various sections which occur in adult animals. Only two kinds can be distinguished: small with a regular lumen, lying among the vesicles - intralobular ducts $(5, a)$ and large, interlobular ducts lying separately in the connective tissue $(5, \mathrm{~b})$. All the elements are separated by a large amount of connective tissue.

The secreting part of the sublingual salivary gland in $26 \mathrm{~mm}$. embryos (Figs. 4,5) is constructed of distinct tubes of a mucous character and of a small amount of the elements described above in the submandibular salivary gland. They are distributed in the form of separate cells, haif-moons, and sometimes even whole vesicles. The serous cells accompanying the mucous tubes also give a small degree of positive reaction to mucus. These are, similarly to those in the rudiments of the submandibular salivary gland, cells similar in appearance to serous elements, but capable of producing a small amount of mucous substance. Its presence may be discovered, particularly in the apical part of the cells. These are muco-serous cells. Their cytoplasm contains a considerable amount of ribonucleic acid.

The mucous cells of the tubes have light-coloured protoplasm and large nuclei, either oval, round or flattened in shape. The secretion contained in the cytoplasm stains with mucicarmine and PAS-ferrum.

The rudiments of the ducts have the same structure here as in the submandibular salivary gland.

The salivary glands of embryos $29 \mathrm{~mm}$. long are of similar structure. A large amount of mucous secretion staining intensively with mucicarmine, PAS-ferrum and aniline-blue can be found in the mucous secreting elements of the sublingual salivary gland (Fig. 6), and in the lumen of the ducts. The nuclei of the cells reveal a large amount of DNA, and the cytoplasm, particularly in the muco-serous cells, a large amount of RNA. There is considerably less caryokinesis here. There is an increasingly large number of secreting elements, but the gland is still threaded by a large amount of connective tissue. Ducts are not differentiated, there 
is no sexual dimorphism present. The division of the gland into lobes is perceptible for the first time.

\section{DISCUSSION OF RESULTS}

The rudiments of salivary glands do not form simultaneously. Of the salivary glands examined, the submandibular gland is formed earliest. In the development of this salivary gland I observed the transition from single accumulations of cells, through the stage of formations possessing a lumen, to vesicles and ducts. The change in the histochemical picture took place parallel to the change in the morphological picture. The celis in the earliest period stain very faintly. The cytoplasm is light in colour, exhibits a very small amount of RNA, polysaccharides and acid mucopolysaccharides. The nuclei are also very light in colour, the response to the Feulgen reaction very slight. Only the outline of the nucleus and a few separate grains of chromatine are clearly visible. With development of the submandibular gland an increasingly large amount of RNA, polysaccharides and acid mucopolysaccharides can be found in the cytoplasm. In embryos $26 \mathrm{~mm}$. long I observed the presence of mucus in the cytoplasm of the cells of vesicles, but there was only a very small amount and it is concentrated mainly in the apical part and in the lumen of the vesicles. In the oldest embryos which I was able to examine, i.e. $29 \mathrm{~mm}$. long, the amount of mucus was slightly greater, and at the same time it appeared in the lumen of ducts. The vesicles of the submandibular salivary gland of the rat embryo, despite the structure typical of serous elements, and the protein substances contents, are capable of producing a mucous discharge, as is the case in the same salivary gland in adult animals (Wimsatt, 1956; Si uda \& Szymańska, 1961). They are therefore also composed of muco-serous cells.

The outlet ducts of the submandibular salivary gland differ, however, fairly considerably from the ducts of the adult animal ( $\mathrm{H}$ i 11 \& B o u r n e, 1954; S ch mid t, 1959; Si uda \& Szy mańska, 1961). I was not able to observe either insertions or granular sections or striate ducts. J a c o b y \& Le e s on (1959) observed the formation of these elements only in animals several weeks old. I observed two kinds of ducts only in embryos: smaller ones, regular, lying between the vesicles, and larger ones with a large lumen, lying separately in the connective tissue. The tissue covers the entire gland, but as the latter develops the amount of tissue decreases in favour of the glandular tissue.

I observed the sublingual salivary gland for the first time in embryos $26 \mathrm{~mm}$. long. The predominant element in its structure is formed by the tubes composed of mucous cells. Near them there is a small number of serous cells, the cytoplasm of which also stains slightly for mucus. The 
mucous tubes are constructed of large, light-coloured cells, of which only a few have flattened nuclei, similarly to the same elements in adult animals. A large number of the nuclei, on the other hand, are oval or even round in shape. The mucous secretion in the young forms of the gland occurs only in the apical part of the cells. In older animals it fills the whole cytoplasm and appears in the lumen of the tubes and ducts. The amount of nuclein acids is far greater than in the sublingual salivary gland of adult animals.

The secreting elements of the submandibular and sublingual salivary glands therefore develop in the embryo until they attain the stage of almost completely formed glands. The salivary glands start their secretory function beginning with embryos $26 \mathrm{~mm}$. long. The ducts in the rudiments of the salivary glands are not differentiated nor completely formed. The development of the ducts probabiy takes place after the birth of the animal.

I did not observe sex dimorphism in the salivary glands which I examined.

\section{SUMMARY}

The authoress observed the development of the submandibular and sublingual glands of the white rat, in material consisting of 42 embryos varying in length from $22-29 \mathrm{~mm}$. The rudiments of the salivary glands were fixed in B o u in, Z e n ker, Lis on-Vok a er fluids and soaked in paraffin. Sections 6 microns thick were stained with haem.-eosine, ferrous haem.-, mucicarmine, "Azan", PAS-ferrum, and also by the Himes-Moriber, Feulgen and Brachet methods.

The earliest rudiments of the submandibular salivary gland of the white rat were observed in embryos $22 \mathrm{~mm}$. long, in the form of compact accumulations of cells, which next become differentiated into ducts and vesicles. Histological and histochemical reactions were very faint during this period. In older $(26 \mathrm{~mm}$.) embryos the vesicles are well formed, the cells composing them contain large spherica? nuclei, increasingly rich in DNA. There is a small amount of mucus in the apical part of the cells. The secreting part of the submandibular salivary gland of the embryos is therefore a vesicular gland composed of muco-serous cells. Pyronin-absorbing capacity of the cytoplasm of the cells increases with the development of the salivary glands.

The sublingual salivary gland was observed in embryos from 26-29 mm. long. This is a tubular salivary gland composed of mucous cells with a small admixture of muco-serous cells.

Among the outlet ducts in older embryos small intralobular ducts, and broader interlobular ducts, are found. The ducts in the rudiments of the salivary glands in older embryos contain mucous secretion in the lumen.

The salivary glands of embryos do not exhibit sex dimorphism. The initially large amount of connective tissue decreases in favour of glandular tissue. Starting with embryos $26 \mathrm{~mm}$. long, the division of the gland into lobes can be observed.

Acknowledgments: I have pleasure in expressing my grateful thanks to Doeent Dr. Helena Lewińs k a, Head of the Dept. of Histology and Embryology, Bialystok Medical School, for her help and guidance in the preparation of this paper. 


\section{REFERENCES}

1. A e ber h a rd t, F., 1936: Beitrage zur Histologie und Histogenese der Unterkieferdrüsen (gl. mandibularis) von Hund und Katze. Ztschr. mikr. Anat. Forsch., 40: $558-585$,

2. B r a n d t, W., 1949: Lehrbuch der Embriologie. S. Karger. Basel.

3. Cl a r a, M., 1940: Entwicklungsgeschichte des Menschen. Quelle Meyer. Leipzig.

4. Chievitz, J. H., 1885: Beitrage zur Entwicklungsgeschichte der Speicheldrüsen. Arch. Anat. Physiol. Anat. Abt., Hefte III-IV: 401-436.

5. Go d l e w s k i, E., 1950: Embriologia zwierząt kręgowych. P.Z.W.L. Warszawa.

6. Gra um an n, W. \& Cla us s, W., 1958: Weitere Untersuchungen zur Spezifität der Histochemischen Polysaccharid-Eisenreaktion. Acta histochem., 6: $1-7$.

7. Hertwig, O., 1910: Lehrbuch der Entwicklungsgeschichte des Menschen und Wirbeltiere. Gustaw Fischer. Jeña.

8. Hill, C. R. \& B o u rn e, G. H., 1954: Histochemistry and cytology of the salivary gland duct cells. Acta anat., 20: 116-128.

9. Himes, M. \& Mor i ber, L., 1956: A triple stain for deoxyribonucleic acid, polysaccharides and proteins. Stain Technology, 31: 67-70.

10. J a coby, F. \& Leeson, C. R., 1959: The post-natal development of the rat submaxillary gland. J. Anat., 93: 201-216.

11. P atte n, B. M., 1946: Human Embryology. The Blakiston Company. Philade!phia.

12. P e a r s e, A. G. E., 1960: Histochemistry theoretical and applied. I. A. Churchill. London.

13. S c hmidt, E. S. G., 1959: Der Einfluss des Winterschlafes, des Megaphenschlafes, der Hungerns und verschiedener Kostarten auf die Speicheldrüsen von Myoxus, Erinaceus europaeus, Mus und Rattus. Ztschr. Zellf. mikr. Anat., 50: 143-182.

14. S i u d a, S. \& S z y m a ń $\mathrm{s} \mathrm{k} \mathrm{a,} \mathrm{Z.,} \mathrm{1961:} \mathrm{Compárative} \mathrm{investigation} \mathrm{of} \mathrm{the} \mathrm{salivary}$ glands of small rodents. Acta theriol., 5, 11: 141-151.

15. S z y m ań s k a, Z., 1962: Morfologiczny i histochemiczny obraz ślinianki podżuchwowej i podjęzykowej zarodka szczura białego. Folia morphol., 13: 195-201.

16. W i m s a t t, W. A., 1956: Histological and histochemical observations on the parotid, submaxillary, and sublingual glands of the tropical american fruit bat, Artibeus jamaicensis. J. morphol., 99: 169-209.

Białystok Medical School,

Dept. of Histology and Embriology,

Białystok, Kilińskiego 1.

\section{EXPLANATION OF PLATES}

Plate VI.

Fig. 1. Rudiments of the salivary glands of a rat embryo $22 \mathrm{~mm}$. long. Stained with haematoxylin-eosine. Magnified $230 \times$.

Fig. 2. Salivary glands of a rat embryo $24 \mathrm{~mm}$. long. Stained with haematoxylin-eosine. Magnified $230 \times$.

\section{Plate VII.}

Fig. 3. Salivary glands of a rat embryo $26 \mathrm{~mm}$. long. Stained with haematoxylin-eosine. Magnified $230 \times$. 
Fig. 4. Submandibular salivary gland (on left) and sublingual gland (on right) of a rat embryo $26 \mathrm{~mm}$. long. Stained with haematoxylin-eosine. Magnified $230 \times$.

Plate VIII.

Fig. 5. As above. Preparation stained with mucicarmine. a - small duct, $\mathrm{b}-$ large interlobular duct. Magnified $230 \times$.

Fig. 6. Sublingual salivary gland of rat embryo $29 \mathrm{~mm}$. long. Stained with mucicarmine. Magnified $230 \times$.

\section{STRESZCZENIE}

Autorka obserwowała rozwój ślinianki podszczękowej i podjęzykowej szczura białego na materiale składającym się z 42 zarodków długości $22-29 \mathrm{~mm}$. Zawiązki ślinianek utrwalano w płynie Bouina, Zenkera, Lisona-Wokaera i zatapiano w parafinie. 6 mikr. skrawki barwiono hem. eozyną, hem. żelazistą, mucikarminem azanem, PAS - żelazem i metodami Himesa-Moribera, Feulgena i Bracheta.

Najwcześniejszy zawiązek ślinianki podszczękowej szczura białego autorka obserwowała u zarodków długości $22 \mathrm{~mm}$. pod postacią litych skupień komórek, które następnie różnicowaly się na przewody i pęcherzyki. Reakcje histologiczne i histochemiczne wypadały w tym okresie bardzo słabo. U starszych $(26 \mathrm{~mm})$ zarodków pęcherzyki są już dobrze uformowane, tworzące je komórki zawierają duże kuliste jądra, coraz bogatsze w DNA. W części szczytowej komórek stwierdza się niewielką ilość śluzu. Część wydzielnicza ślinianki podszczękowej zarodków jest więc gruczołem pęcherzykowym zbudowanym z komórek śluzowo-surowiczych. Pyroninochłonność cytoplazmy komórek wzrasta w miarę rozwoju ślinianki.

Slinianka podjęzykowa obserwowana była u zarodków długości $26-29 \mathrm{~mm}$. Jest to ślinianka cewkowa zbudowana z komórek śluzowych z niewielką domieszką komórek śluzowo-surowiczych.

Wśród przewodów wyprowadzających u starszych zarodków stwierdza się małe przewody śródzrazikowe i szersze - międzyzrazikowe. Przewody w zawiązkach ślinianek starszych zarodków zawierają w świetle wydzielinę śluzową.

Slinianki zarodków nie wykazują dymorfizmu płciowego. Początkowo duża ilość tkanki łącznej ulega zmniejszeniu na rzecz tkanki gruczołowej. Począwszy od $26 \mathrm{~mm}$. długości zaznacza się podział gruczołu na zraziki.

Nakład 1400 egz. Ark. wyd. 1. Maszynopis otrzymano 20.III.63 r. Podpisano do druku 15.V.63. Druk ukończono 30.V.63. Papier druk. sat. III kl, 80 g. Format B5. Cena $5 \mathrm{zl}$. 


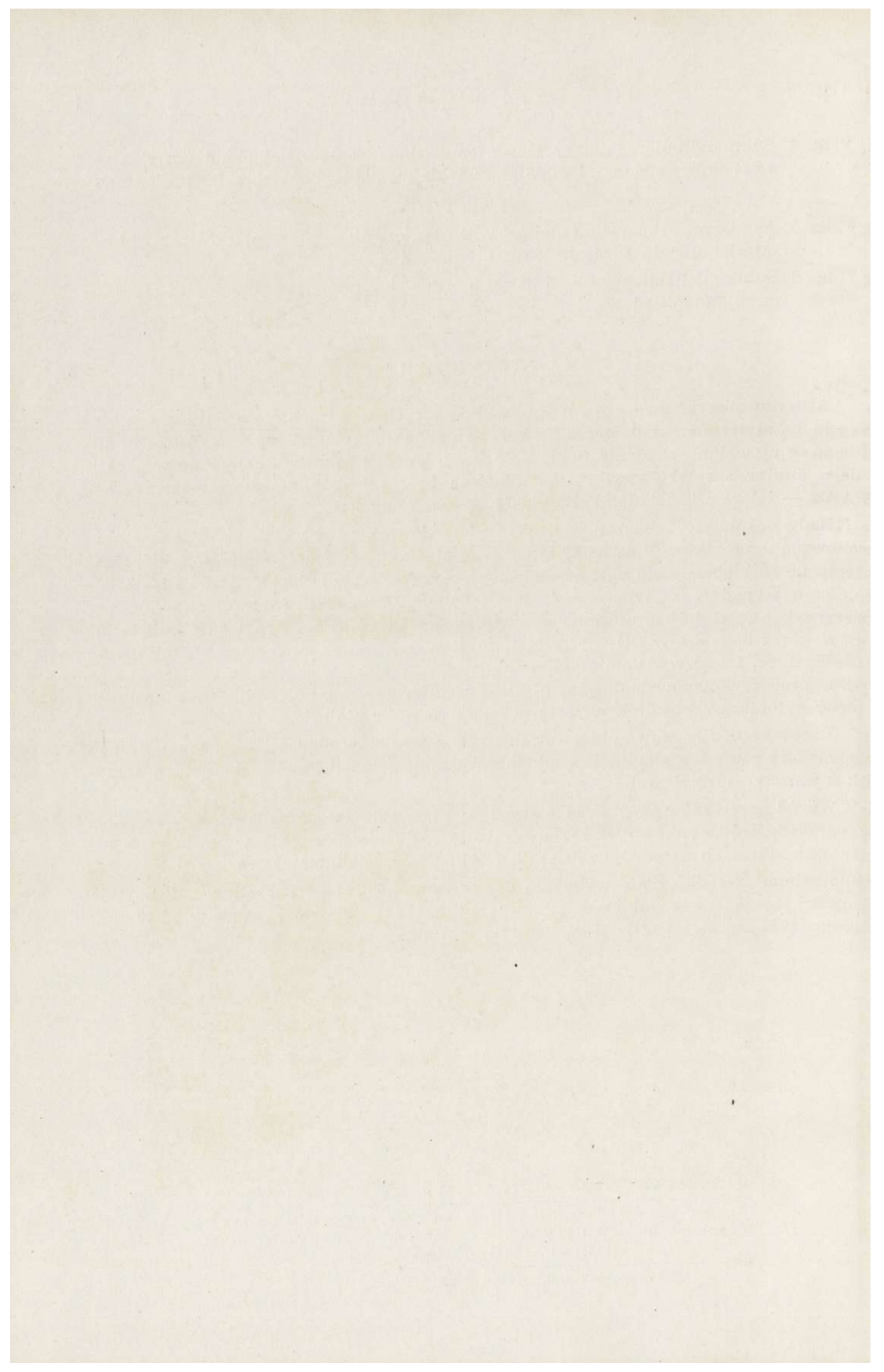



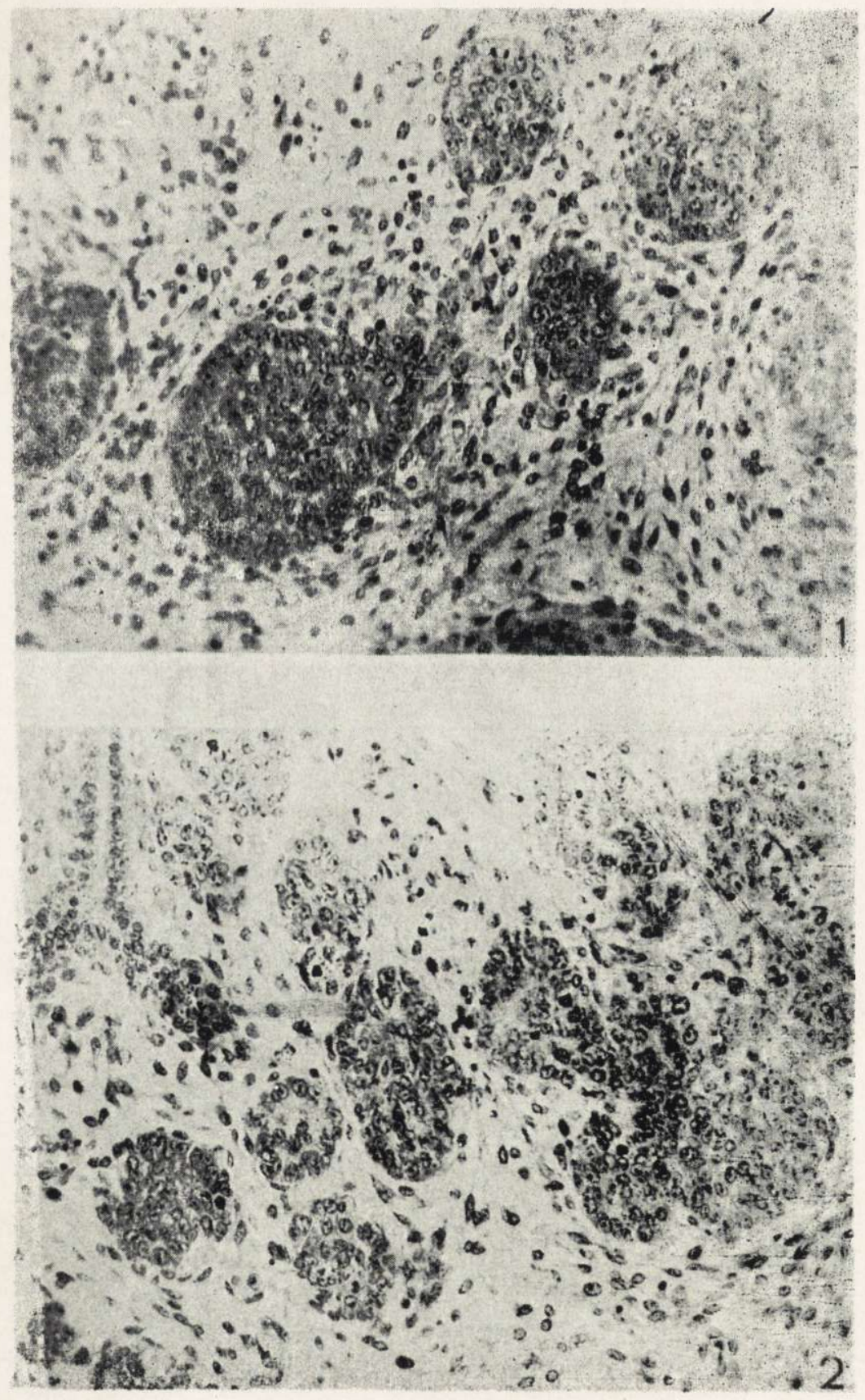

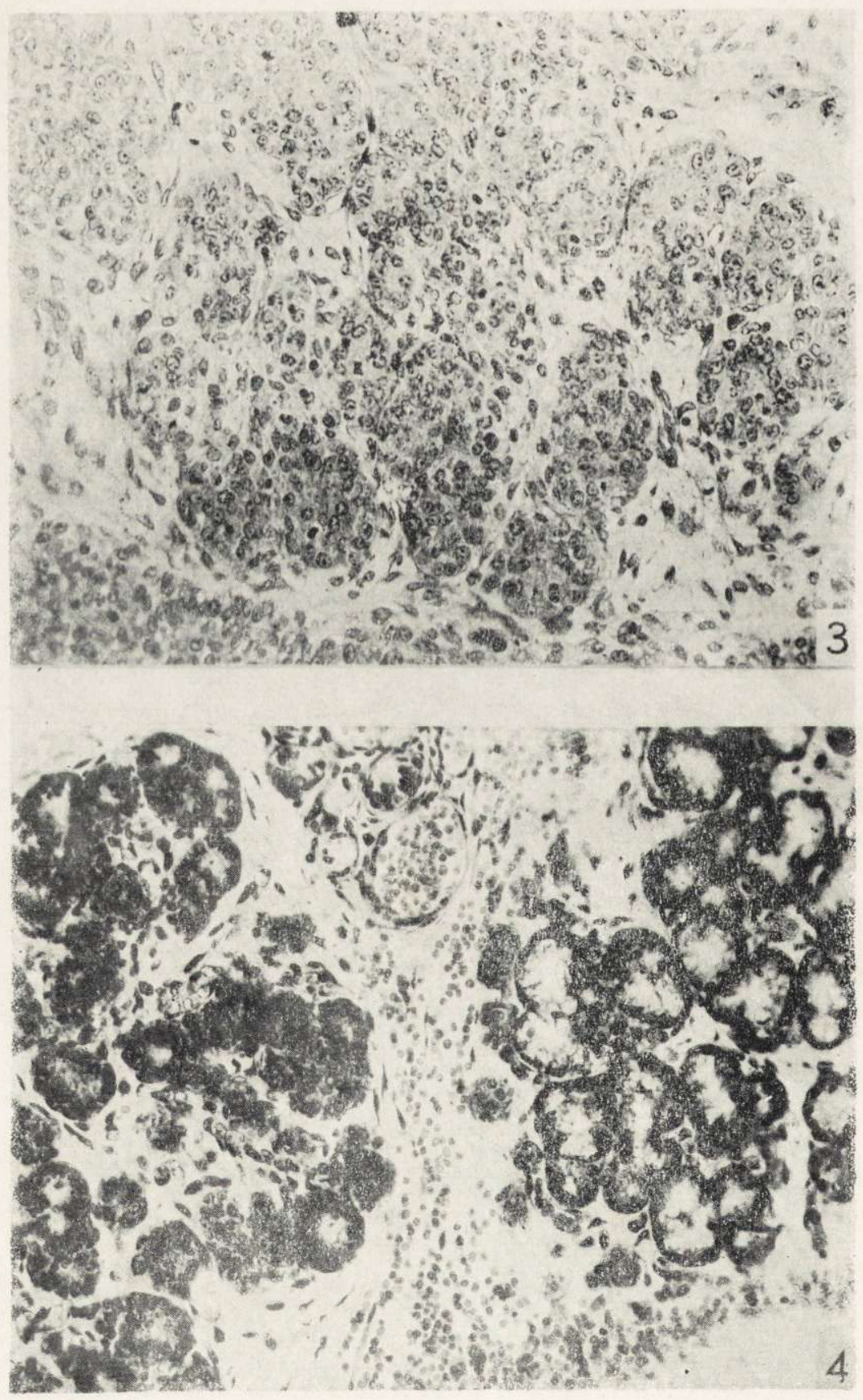


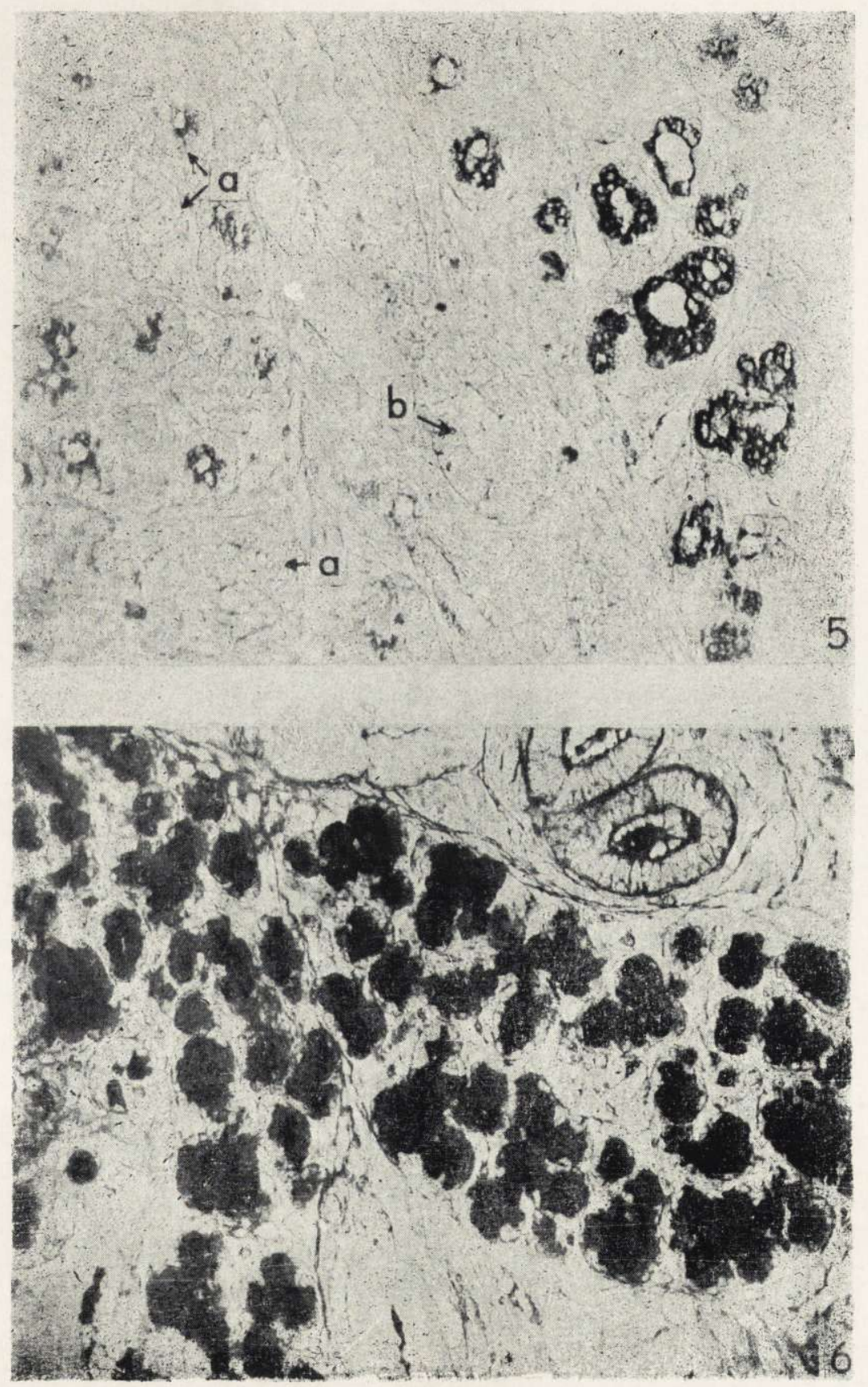


BIBLIOTEKA

Instytutu Biologii Ssaków

Polskiej Akademii Nauk

NrCz. 40.2 